\title{
MARKETING PROBLEMS AND PROMOTION IN THE SALE OF PRODUCTS FROM SMALL WOODLOTS ${ }^{1}$
}

\author{
BY LAWRENCE S. HAMILTON ${ }^{2}$
}

Professor Lawrence S. Hamilton was born in Toronto, Ontario and received his undergraduate forestry training at the Faculty of Forestry, University of Toronto. He received the M.F. degree from the New York State College of Forestry in 1950.

Professor Hamilton served three years as Zone Forester for the Ontario Department of Lands and Forests and left this position in 1951 to become Extension Forester at the New York State College of Agriculture, Cornell University. In 1954 he shifted to teaching and research at the same institution and now heads the graduate program in natural resources conservation. He is Director of Cornell's Arnot Forest. He is currently Chairman of the New York Section, Society of American Foresters as well as a member of the Canadian Institute of Forestry.

\section{$A B S T R A C T$}

This paper summarizes for an audience of Ontario woodlot owners and foresters what seem to the author to be the main woodlot marketing problems in New York State. Some of the programs and educational materials which have been developed in New York are briefly described as possible guidelines for marketing assistance in Canada.

\section{INTRODUCTION}

According to a recent survey of marketing in the Northeastern United States (8) 61 per cent of the saies made from small privately-owned woodlots were made by persons who had no presale information on markets for their products. ${ }^{3}$ Moreover in only 37 per cent of all sales did the owners know how much timber they had to sell! The same degree of marketing ignorance probably does not quite obtain in Ontario, due primarily to the smaller proportion of absentee owners and rural non-farm owners. Anything even approaching this degree would indicate that our conference theme is indeed appropriate.

Josh Billings is reported to have said "It ain't so much that people are ignorant, it's just that they know so much that ain't so." While this statement may characterize much of our social and commercial life, it does not seem applicable in the field of forest products marketing. Lack of information overshadows misinformation, and creates a situation far removed from the idealized "perfectly competitive market."

${ }^{1}$ Based on a paper given at Conference on the Marketing of Farm Woodlot Products in Ontario held November 1960 in Toronto.

2 Associate Professor of Forestry, Cornell University, Ithaca, N.Y.

3 This survey did not include the marketing of maple products (syrup, sugar or cream) or Christmas trees. 
For the optimum allocation of resources under the free enterprise pricing system, both buyers and sellers should be fully informed, there should be a sufficient number of both so that no individual can influence the price, and the product should be homogeneous. Let us look briefly at the areas in which forest product marketing from small woodlots falls short of this concept, and then discuss the activities which have evolved, aimed at improving marketing practice.

\section{Imperfect Competition Characterizes Present Marketing Practices}

\section{(a) Buyers are not fully informed}

While those buying stumpage or products from small woodlots are more fully informed than the sellers, there is still a great deal of room for improvement. When so much timber is in small parcels and in the hands of large numbers of woodlot owners, buyers are often unaware of who or where the sellers are. In New York for instance, one-half of the commercial forest is in the hands of some 238,000 private holdings of less than 100 acres in size (1). Ferreting out sellers thus becomes a major task in wood procurement. Buyers initiate probably 28 per cent of the sales made from small woodlots (8).

In spite of the volume of material published on the subject, many smallscale buyer-operators are still unaware of the zero-profit size tree. They continue to pay stumpage for, and extract from the woods, trees of small size whose "conversion surplus" is zero or a negative amount. In so doing, they are scarcely behaving like fully-informed buyers. Many of these buyers are also not cognizant of the advantages of purchasing forest products from woodlots which have been marked and estimated by foresters. Some buyers say that once the reliability of the forester's estimates has been proved to them, they prefer to buy marked woodlots. They know in advance the volume by size and species, their cutters find it easier to cut marked trees rather than making decisions which will not violate the owners' wishes, and they are able to visualize making successive cuts of better quality and size when good growing stock is protected. Unfortunately, many other buyers have told me they would have nothing to do with any marked woodlots. Perhaps in their cases Josh Billings is correct.

\section{(b) Sellers are not fully informed}

The forest owner departs even more drastically from the concept of a fully-informed seller. First of all, he seldom knows which trees he should be offering for sale. The identities of the financially mature trees and those of merchantable size but returning satisfactory interest rates, are largely unknown to woodlot owners. Ontario's county diameter-limit cutting laws have served to set lower limits to maturity and protect many trees earning high rates of financial interest, but the financially mature, ready-for-market trees need further identification on both sides of the Border. Secondly, owners are not aware of how much they have to sell (whether mature or not). Only 37 per cent of the sales from 1947 to 1951 in the Northeast were made by owners who knew prior to selling how much timber they were offering (8). Few owners know how to estimate the volumes of standing trees. Even when it came to measurement or count of the product for payment, this same study showed 67 per cent 
of the sales were made by the owner's acceptance of the buyer's measure. Log scaling or measuring of other forest products except maple products and Christmas trees are not skills possessed by very many woodlot owners. Moreover, woodlot owners are generally unaware of the possible market locations for the products and the diversity of products which their woodlands might produce. The marketing survey previously referred to showed that 61 per cent of the sales were made with no advance knowledge of markets, and 64 per cent of the sales were of a single product per cutting (8). This lack of market information also carries over into the area of price determination, with 64 per cent of the sales being made on the basis of one buyer's offer. Only 14 per cent of the sales were made by competitive price bidding. Finally, there is also a strange lack of awareness on the part of woodlot owners that they can sell their labor as well as their raw wood, thus giving what the economist would call greater utilities of form and of place. Few farmers would consider selling milk in the cow's udder, or wheat "stalkage", yet will sell timber stumpage even though they have the necessary equipment (or could easily acquire it) to partly process the standing trees.

\section{(c) Numbers}

The truly competitive market situation is not attained in some instances because of certain monopsonistic tendencies. There are usually plenty of sellers so that they cannot influence the price, except in some areas where the bulk of the land may be held in public ownership such as a National Forest. This may also be true where Ontario Crown Land represents a large portion of the operating area of one or more buyers. Some Christmas tree growers in the past have had this favorable situation with respect to Scotch pine or Douglas fir, and even today some maple syrup producers can influence price within certain limits before products are brought in from other areas. The more common situation however is where one or a few buyers purchase certain products, such as pulpwood, and can establish a price in a captive marketing area. There are most certainly quasi-agreements or tacit understandings among many forest products buyers as to the general prices paid.

(d) Non-homogeneous product

Those marketing forest products also find they have products which are not homogeneous. Logging chance, nearness to market, timber quality all make for differentiation which should, and frequently does, influence price, but which reduces the purely competitive market situation. Even where products are graded, seller unfamiliarity with grades of products which he markets relatively infrequently, often spells confusion. Such confusion precludes optimum allocation.

\section{Some Activities Aimed at Improving Marketing Procedures}

(a) Published information to make buyer and seller aware of each other's existence

Many Extension Foresters or State Forestry Departments publish lists of buyers and the products they are seeking. Such a compilation has been made by the New York State Department of Conservation (7) in its "Primary WoodUsing Plants in New York". One of the major problems of this type of statewide information is the rapid obsolescence because of turnover of firms. A 
very useful marketing function is performed by a marketing bulletin which is issued every six weeks to a mailing list, by the State University of New York, College of Forestry. This bulletin is open to free advertisement by buyers and sellers of forest products or equipment used in logging or wood processing. Buyers and sellers are identified only by number and county, and are put in direct contact through the wood utilization service of the College. Last year the New York State Department of Agriculture and Markets began including in their Christmas tree crop reports a section on trees being offered for sale or trees wanted. Again, the buyers and sellers are identified by number only. The other important facet of published information consists of paid advertisements inserted by either buyer or seller in daily newspapers, county extension service news, farm papers and journals such as the Northeastern Logger.

\section{(b) Published price information}

Market reports giving volume of sales and prices have long been available to farmers for many of their crops. Such price reporting has not been extended to forest products with the exception of Christmas trees and maple products. For example, the New York State Department of Agriculture reports sale volumes and prices of Christmas trees. These reports are issued weekly from around the first of October till just before Christmas.

Average or general price range by species and forest district, for stumpage and delivered forest products, appears in the quarterly publication of the New York Forest Practice Act program. This bulletin is received by most professional foresters who are concerned with woodlot management, and by the local district board members who set the policy for this program (equivalent in some ways to Ontario Tree Cutting Commissions). Price information thereby gets into the hands of those who may be called upon for marketing advice, but does not reach the producer directly.

\section{(c) Producers' associations}

While layman's forestry associations exist on both sides of the Border, they have not taken as one of their functions the provision of the kind of current and fairly specific marketing information which woodland owners need. Specialty producers' organizations can do this, and have been formed, essentially to improve marketing practices, in many states and provinces for at least two forest products-Christmas trees and maple syrup. In New York, the Maple Producers' Associations have performed yeoman service both in promoting consumer demand for maple products and in promoting improved marketing practices among their members. This work has been ably assisted by the Extension Foresters, and production and marketing research carried on at the College of Agriculture. This type of working relationship between producers' associations and university research and extension is quite common south of the Border.

\section{(d) Technical forest management service}

Consulting foresters are available to perform complete management services for the owners-from the designation of the ready-for-market products to the consummation of the sale and receipt of the payment. An everincreasing number of owners of even small woodlands are finding that the 
cost of such service is well worthwhile in terms of net income and satisfaction received. The Extension Foresters have compiled a list of consultants in New York State as an information service to woodland owners.

Many states also provide publicly employed foresters to give a certain amount of management service and marketing help. Under New York's Forest Practice Act, state service foresters are authorized to provide cooperators with: marking of the trees for harvest cut or stand improvement; estimation of the volume marked; a list of possible markets; a range of current prices; a sample sale contract; a map and management plan. This service is provided without charge to those who agree to follow the marking and the cutting practice standards set up by local boards (5). Most of the Northeastern States have programs which provide somewhat similar services. Some states charge for the marking, some charge only if the marking is not adhered to. Buyers are increasingly visiting the state service foresters for news of timber which has been marked and on which they might bid.

\section{(3) Brokers or agents}

For many years brokers have operated in the pulpwood procurement field on behalf of the buyers. Brokers or agents for the producer have been fairly rare in the Northeast. There are a few in New York, primarily in connection with Christmas tree marketing. Timber agents acting on behalf of the landowners are well established in New Jersey. There, the public service program is combined with the use of a timber agent who is approved by the State. He takes over after the marking and estimating, and for 10 per cent of the gross sale value, solicits bids, draws up the contract, enforces compliance with marking and contract, measures products and collects the money (6). Incidentally, while I was Zone Forester at Hespeler, Ontario, I patterned a marketing experiment on this New Jersey system with excellent results (2).

\section{(f) Concentration yards}

The chief function of concentration yards is to serve as assembly points for specialized products which come in small amounts from diverse sellers. By this device enough material is assembled to make sales to distant markets possible. We have very few of these in the Northeast for primary forest products and we might well devote attention to methods of encouraging their establishment.

\section{(g) Auction}

Auction of primary forest products is a real rarity in marketing practice from small woodlots. This method has recently appeared in New York, in connection with Christmas tree sales. While these have been generally successful, there are some serious disadvantages with a "perishable" product such as cut Christmas trees, which must be sold at the auction, or incur costly rehandling and further marketing difficulties.

\section{(h) Cooperatives}

The cooperative marketing agency seems like a logical answer to many of the problems facing sellers who own small woodlots, yet its performance has seldom lived up to its promise. Most of the cooperatives which were 
formed in the United States particularly during the depression years, have petered out, though a few have remained viable and serve to illustrate the value of this marketing device. In New York at the present time we have the Maple Producers' Cooperative Association and the Otsego Forest Products Cooperative Association. The latter is not only a marketing agency, but a processing cooperative with a sawmill and planing mill at Cooperstown, N.Y. The association also provides forest management service to its cooperators. Although initially cited as one of the most successful forest product cooperatives in the country, it is currently experiencing very serious difficulty.

\section{(i) Buyers' programs}

Many buyers attempt what is referred to as "non-price" competition", through public relations or providing certain extra services which make their price seem more attractive to a seller. Larger sawmillers and the pulp and paper companies in particular offer such service items as free timber marking, free reforestation stock or tree planting services. The building of goodwill by providing public hunting on company lands, or picnicking facilities may often result in a company being given first chance to buy an owner's timber. Recently, encouraged by the American Forest Products Industries Incorporated, some companies have established "Tree Farm Family" programs. American Box Board's program of service includes: a guaranteed market for all pulpwood produced to specification; assistance in marketing other forest products; a management plan; marking service; tree planting advice and the use of planting machines; a Tree Farm recognition sign and certificate; and a free subscription to the American Tree Farmer. In return the owner agrees to permit the company to have the first opportunity to purchase the pulpwood at current market prices.

\section{(j) Grading}

The establishment and use of grades is an extremely useful marketing device. This improves communication and satisfaction between buyer and seller who are dealing with a product of non-homogeneous quality. It results in benefiting the producer of high quality forest products who is, in the absence of grading, being penalized by poor quality material. Grades have now been established nationally in the United States for maple syrup and Christmas trees. Logs are graded by some buyers, and paid for on this basis but no state-wide or nation-wide standards have been recognized.

\section{(k) Continuing educational and research programs}

Public forestry agencies and universities have for many years carried on general programs of marketing education and specific research projects in utilization and marketing. Yet approximately 51 per cent of the sales made from 1947 to 1951 were made without any awareness that management or marketing assistance were available from either public or private sources (8). Certain of these programs are most important if we are to improve marketing practices from small woodlots.

For one thing, more information is needed to help owners identify the financial maturity size based on economic increment. This concept was first proposed in this country by Heiberg (4), and establishes guides for determining the upper size limit at which a tree will no longer, through its growth, yield 
an interest rate which is acceptable to the owner. Information is also needed on the income possibilities for owners who will carry out at least part of the harvesting and delivery process, as well as on the income available through periodic harvests of the wood itself. We now have 29 years of records of annual wood harvest by an individual woodlot owner in New York, who has earned on the average over $\$ 1.50$ per hour during that period (and has increased the constant dollar value of his woodland in that period). Our Department of Agricultural Economics at Cornell maintains records on certain cooperating farms of the hourly labor returns for various enterprises including wood harvesting. We have a selection of these cost account farm records where the woods enterprise ranks among the most successful of all of the enterprise on the farm. ${ }^{*}$ We also have underway a woodland enterprise study patterned on the system first developed in New Hampshire. This study aims at: providing data to enable the woodland owner to best fit his woodland operations into his other farm enterprises; showing the owner how much income the forest is contributing to his farm business; providing examples for the promotion of forestry programs.

Continuing information is needed concerning the merits of using written sale contracts and the essentials which should be included. Over 80 per cent of the sales are conducted on the basis of verbal agreement (8). Woodlot owners can be given some familiarity with product measurement methods. A public service bulletin entitled "How to measure logs" has been published in New York (9). Incidentally, need for the seller to worry about log scaling could be eliminated if we encouraged competitive lump sum bidding on marked timber where a reliable estimate was available. This, in my opinion, is the best way to sell standing sawtimber. Public agencies or universities need to carry out research in marketing, since woodlot owners are not generally organized into groups that can carry on research or financially support it. Market surveys are needed to determine consumer or buyer preference and specifications, so that products can be grown to meet the most profitable ends. Typical of such studies is one recently carried out concerning consumer preferences for Christmas trees (3). Finally, continuing research to probe for new uses of wood, so that a greater proportion of what is grown in our woodlots can be profitably marketed, is the key to making the forest resource better serve the interests of the owner and society in general.

RIDER

This enumeration of marketing activities shows how we in New York have approached problems which are of pressing concern in Ontario. The ways in which you are meeting these same problems probably will have some marked differences. This is eminently desirable, because as Josh Billings reported a wise Indian brave as saying "Good not all men think same, or every man want my squaw."

"Income from the farm woodland", compiled by G. R. Cunningham. Mimeographed. Dept. of Conservation, Cornell University, Ithaca, N.Y.

\section{REFERENCES}

1. ARMSTRONG, GEORGE R. and JOHN C. BJORKBOM. 1956. The timber resources of New York. Northeastern For. Expt. Sta., U.S. For. Service, Upper Darby, Pa.

2. HAMILTON, L. S. 1951. Marketing farm woodlot products. For. Chron. 27 (3): 228-232. 3. 
Christmas tree buying habits. Dept. of Conservation Mimeo Leaflet C 22, Cornell Univ. Ithaca, N.Y.

4. HEIBERG, SVEND O. 1942. Cutting based upon economic increment. Jour. For. 40 (8): 645-651.

5. LITTLEFIELD, E. W. (No date). The New York Forest Practice Act. N.Y. State Conservation Dept. For Bull. 21, Albany, N.Y.

6. MOORE, E. B. and A. N. LENTZ, 1951. The cooperative forest management program in New Jersey. Jour. For. 49 (1): $31-34$.

7. NEW YORK STATE CONSERVATION DEPARTMENT. 1954. Primary wood-using plants in New York. Albany, N.Y.

8. NORTHEASTERN REGIONAL TECHNICAL COMMITTEE. 1956. Marketing forest products from small woodland areas in the Northeast. Selling practices of woodland owners and extent of home use of timber products. Northeastern Regional Publ. 25, Burlington, Vermont.

9. PLUMLEY, LUCIAN P. 1959. How to measure logs. Dept. of Forest Extension, State Univ. College of Forestry, Syracuse, N.Y. 